\title{
Evaluation of surface water storage: supply infrastructure of a river basin in a semi-arid region
}

\author{
A. Zende \& R. Nagarajan \\ Center of Studies in Resources Engineering, \\ Indian Institute of Technology, Bombay, India
}

\begin{abstract}
The sustainable water availability in a semi-arid region is achieved by construction of permanent/temporary water storage systems and distributory networks. Their functional status is crucial for regional development. The objective of this study is to develop methods in evaluating the functional status of water storage supply infrastructures. In addition to the thematic map, orbital satellite (IRS) images and ground based information were used in assessing the storage capacity and physical conditions of Yerala River basin, part of Krishna River basin in India. Assessment of Water infrastructure condition (WIC) was carried out based on Reservoir Storage Efficiency (RSE) and canal conditions (CC) were developed. The storage and distribution systems are functioning at 38 to $68 \%$ of their capacity.

Keywords: Yerala River, Krishna River, semi-arid region, water storage capacity, sustainability of water, water infrastructure condition (WIC) reservoir storage efficiency (RSE), canal conditions (CC), multi-criterion analysis, supply and demand analysis.
\end{abstract}

\section{Introduction}

The deficit of water availability is calculated based on the supply and demand of a region and expressed as stress, scarcity and vulnerability. The fresh water availability in semi-arid and arid regions is subjected to situations such as: 1) demand exceeds availability, 2) non-availability of water infrastructure or poorly managed systems, 3) ground water extraction exceeds recharge, leading to quality and quantity issues, 4) uncertainty of rainfall amount, time and place, 
5) drought situations etc. The climate change could adversely affect the stress conditions. Many countries have developed their water infrastructures (storage, distribution and agriculture / drinking water) towards their development. Ground water as supplementary source in the water supply system has become the easy target in meeting the additional water demands. This has lead to fall in the ground water level. Surface water (as a supply source) availability in the tropical monsoon region depends on the rainfall amount and storages. A detailed analysis of supply (in terms of storage) and demand scenario is essential.

Performance of irrigation system is focused on internal processes of irrigation schemes. It is related to the management objectives such as the area irrigated, crop patterns and distribution and delivery of water (Bos et al. [1]). Temporal irrigation performance assessment of Menemen, Turkey was evaluated by case study by Kukul et al. [2]. These process indicators have been developed to assess the quality of operational performance. The reliability, resilience and vulnerability were estimated in the risk assessments of water resources systems by Kjeldsen and Rosbjerg [3]. Jain [4] used the behavior of statistical indices for performance assessment of a reservoir. Vogel et al. [5] applied the storagereliability-resilience-yield relations for over-year water supply systems. Molden and Gates [6] have proposed nine external and other comparative indicators which will allow for comparison between countries and regions, different management types and environments, and for assessment over time of the trend in performance of a specific irrigation scheme. These comparative indicators have been used to assess the temporal and spatial variations of agricultural water use, environmental and financial performances of irrigation systems (Kloezen and Garce's-Restrepo [7]). Very few of the studies have evaluated the impacts of management interventions, e.g. irrigation management transfer. There is a need for the existing water infrastructures assessment and plan for the future.

\section{Objective}

The objective of this study is to evaluate the water infrastructures (reservoir/tanks and canals/other distributaries) aiding in the water supply on a river basin scale.

River basin located in the semi-arid region, having rain-shadow region as their catchment, several water infrastructures - reservoirs, canal system, lift irrigation system of irrigation and natural tank has been selected. One among the tributaries of Krishna River, India - Yerala River basin has been identified for this study.

\section{Materials and method}

Meteorological information such as rainfall, temperature and humidity was collected from the ten rain gauge stations (point source), terrain, drainage network and water infrastructure information (Spatial information) were collected survey of India Topographic sheets (contour and elevation), Indian Remote sensing satellite images (vegetation, surface water bodies, canals) and 
lift irrigation scheme (irrigation department) and population information from the Census of India. ArcGIS 9.3 was used in digitization and integration of spatial and point information and creates a geospatial data base. Extensive field visits were made in the physical assessment of reservoirs (sedimentation. Embankment, sluice gate), canal conditions and benefits (crop area, constraints).

\section{Yerala river basin - study area}

Most of the Rivers (Mahnadi, Krishna, Godavari, and Cauvery) in the peninsular part of India originate from the mountain ranges located in the west. They receive maximum monsoon rainfall $(>1100 \mathrm{~mm})$ and flows through the semi-arid regions before it joins the sea in the east (Bay of Bengal). These rivers have issues related to water sharing. Studies are underway in the Water demand and supply scenario of these rivers in India. Yerala River (area $3035 \mathrm{sq} \mathrm{km}$ ) is the tributary of Krishna River basin, located in the upper Krishna basin (fig. 1). Its catchment is in the rain shadow region. Several water infrastructures' were developed in this basin. Agriculture based development and drinking water for part of the settlements depend on the existing water infrastructures (15 to 60 years old). This rain shadow region receives annual rainfall ranging from $300 \mathrm{~mm}$ to $1000 \mathrm{~mm}$ (from 1998 to 2011 observations) reported from 10 rain gauge stations located within the basin area and on its periphery.

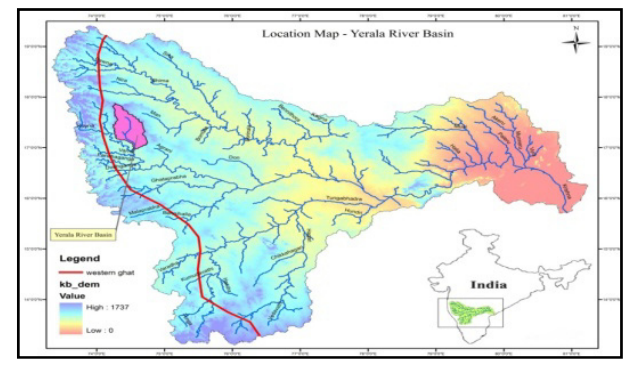

Figure 1: $\quad$ Location of Yerala river, tributary of Krishna river basin, India.

There are six reservoirs of medium / normal storage capacity and few of them have canal distribution arrangement. 170 ponds/lakes without any distribution are available. Lift irrigation system (Takari Lift Irrigation System) - lifts water (through electric pumps) to the height of $130 \mathrm{~m}$ from River Krishna, collect it in a chamber and distribute through $140 \mathrm{~km}$ length of canal system. $88 \mathrm{~km}$ length of the canal system is within the Yerala basin and irrigates mainly sugar cane crop (Zende and Nagarajan) [8]. Spatial distribution of Reservoir, canals, lift irrigation scheme and natural tanks are shown in fig. 2. These infrastructures were assessed for their effective utilization. 


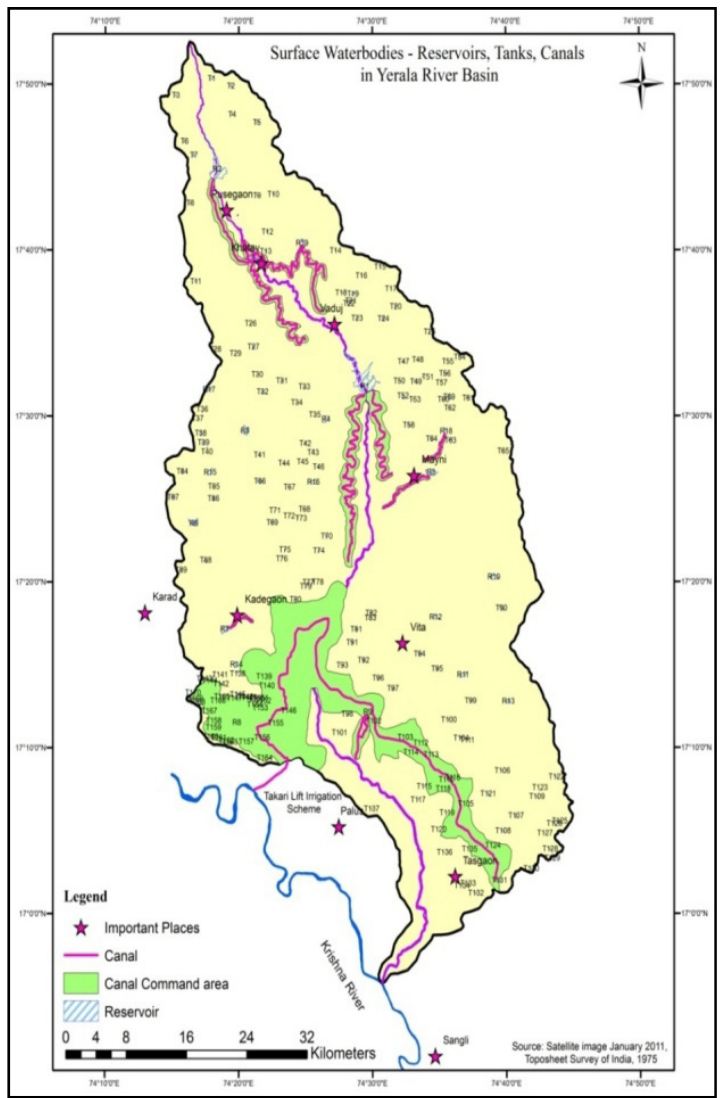

Figure 2: $\quad$ Surface water infrastructures - reservoirs, command areas, canals and tanks.

\section{Assessment of water infrastructure}

Water resources' engineers employ reliability, resilience and vulnerability indices, in assessing the performance of a reservoir. In semi-arid regions, Evaporation losses are high and if these are ignored, one may overestimate the reliability of the reservoir by up to $10 \%$. Multi-criterion decision making methods have been developed and applied in river basin planning (Srinivasa Raju [9]). Water infrastructures are evaluated based on their functional potential (physical condition), effectiveness (storage or conveyance loss), and benefits in decision making processes (existing system improvement or new system) using multi-criteria approach.

Reservoir storage efficiency (RSE) is assessed by - sedimentation (S1) (water storing capacity), condition of embankment (E1) (potential leakage), and sluice gate operation (SG1) (water release). They were grouped into five classes maximum value indicates the intense difficulty in operation (sustained operation 


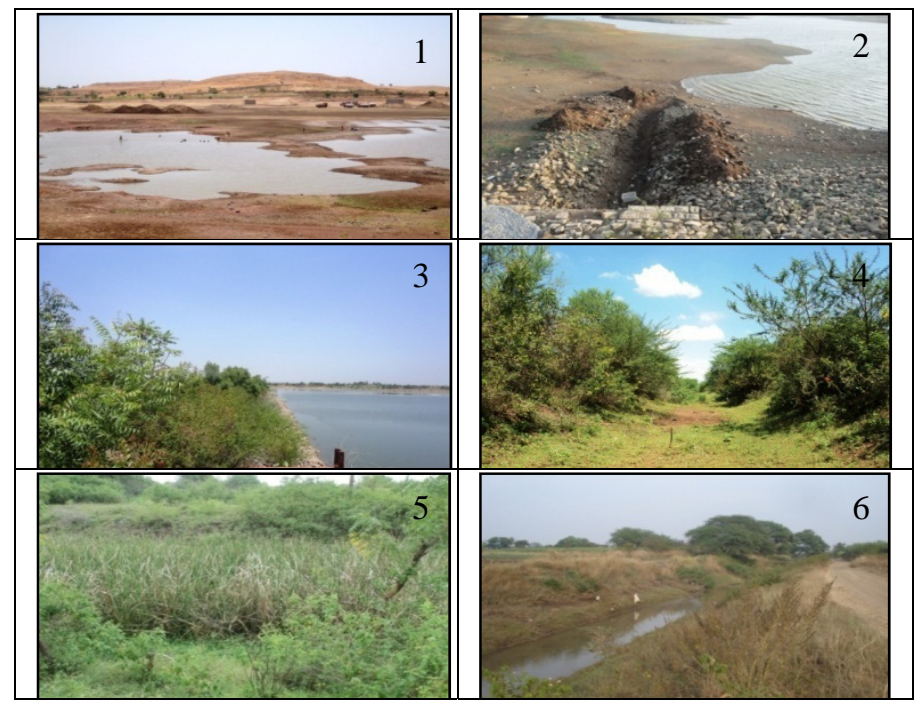

Figure 3: a) Reservoir conditions - 1. Sedimentation, 2. Sluice gate below the water level, 3. Cracks and tree growth on embankment and b) canal condition - 4. Sediments and embankment vegetation growth, 5. Water stagnation and weed growth adjacent to embankment, 6. Bank collapse.

is not smooth) and minimum value opines the easiness (continued dependability). They were ranked depending on their contribution in the sustainable operation. It was observed from the inventories on the reservoirs (about 75) and canals in the Yerala river basin and adjoining areas that $50 \%$ of the reservoir systems are not effective due to sedimentation (S1), 35\% due to weak/damaged embankments (E1) leading to leakage and $15 \%$ due to condition of the sluice gate operations (SG1). Non-function of reservoir is the cumulative contribution from said factors. Weightage to individual parameters in water storing was assigned. The observed degraded condition of reservoir is shown in fig. 3.a. The observation and information from the reservoir was used in assigning their functions. Table 1 shows the physical condition assessment of reservoirs.

RSE $=\sum($ S1rank $x$ weightage $)+($ E2 rank x weightage $)+($ SG1 rank $x$ weightage $)$

The stored water is conveyed / transported to the agriculture plots through lined or unlined open canals. The problems associated with free water movement in canals are - bank collapse (BC), sediment deposition and scouring of beds etc; water pools (WP) (mainly attributed to sediment deposition); weed growth within the canal; seepage across the embankment and weed growth (WG). The observed degraded condition of reservoir is shown in fig. 3.b. The ground based information collected was used in ranking and weightage to individual 
Table 1: $\quad$ Physical condition assessment of reservoir.

\begin{tabular}{|c|c|c|c|}
\hline Parameters & Class & Rank & Weightage \\
\hline \multirow{5}{*}{$\begin{array}{l}\text { Sedimentation level (with } \\
\text { reference total capacity) (S1) }\end{array}$} & $<10 \%$ & 1 & \multirow[t]{5}{*}{50} \\
\hline & $11-30 \%$ & 2 & \\
\hline & $31-50 \%$ & 3 & \\
\hline & $50-70 \%$ & 4 & \\
\hline & $>71 \%$ & 5 & \\
\hline \multirow{5}{*}{$\begin{array}{l}\text { Embankment (damage - in \% } \\
\text { of total length) (E1) }\end{array}$} & $<10 \%$ & 5 & \multirow[t]{5}{*}{35} \\
\hline & $11-20 \%$ & 4 & \\
\hline & $21-30 \%$ & 3 & \\
\hline & $31-50 \%$ & 2 & \\
\hline & $>51 \%$ & 1 & \\
\hline $\begin{array}{l}\text { Sluice gate operation - level of } \\
\text { sedimentation with reference to } \\
\text { gate opening (SG1) }\end{array}$ & $\begin{array}{l}\text { Below } \\
\text { Close to gate } \\
\text { Same level of gate } \\
\text { Above the gate level }\end{array}$ & $\begin{array}{l}5 \\
4 \\
3 \\
2\end{array}$ & 15 \\
\hline
\end{tabular}

Table 2: $\quad$ Physical condition assessment of canals.

\begin{tabular}{|c|c|c|c|}
\hline Parameters & Class & Rank & Weightage \\
\hline \multirow{5}{*}{$\begin{array}{l}\text { Bank collapse (\% of total canal } \\
\text { length) (BC) }\end{array}$} & $<10 \%$ & 5 & \multirow[t]{5}{*}{30} \\
\hline & $11-30 \%$ & 4 & \\
\hline & $31-50 \%$ & 3 & \\
\hline & $50-70 \%$ & 2 & \\
\hline & $71 \%>$ & 1 & \\
\hline \multirow[t]{5}{*}{ Water pooling in canal (WP) } & $<10 \%$ & 5 & \multirow[t]{5}{*}{20} \\
\hline & $11-20 \%$ & 4 & \\
\hline & $21-30 \%$ & 3 & \\
\hline & $31-50 \%$ & 2 & \\
\hline & $51 \%>$ & 1 & \\
\hline \multirow[t]{5}{*}{ Weed growth (WG) } & $<10 \%$ & 5 & \multirow[t]{5}{*}{10} \\
\hline & $11-30 \%$ & 4 & \\
\hline & $31-50 \%$ & 3 & \\
\hline & $50-70 \%$ & 2 & \\
\hline & $71 \%>$ & 1 & \\
\hline \multirow{5}{*}{$\begin{array}{ll}\text { Conveyance } & \text { loss } \\
(\text { evaporation }+ \text { Seepage) }\end{array}$} & $<10 \%$ & 5 & \multirow[t]{5}{*}{40} \\
\hline & $11-30 \%$ & 4 & \\
\hline & $31-50 \%$ & 3 & \\
\hline & $50-70 \%$ & 2 & \\
\hline & $71 \%>$ & 1 & \\
\hline
\end{tabular}

parameters (similar to reservoir assessment). The observation and information (table 2) from the canal site was used in canal condition (CC).

$(\mathrm{CC})=\sum(\mathrm{BC}$ rank $\mathrm{x}$ weightage $)+(\mathrm{WP}$ rank $\mathrm{x}$ weightage $)+(\mathrm{WG}$ rank $\mathrm{x}$ weightage $)$ + (CL rank $x$ weightage) 
The water infrastructure condition (WIC) is the product of reservoir storage efficiency and canal conditions. This could be used for prioritizing the infrastructures.

$$
\mathrm{WIC}=\sum \mathrm{RSE}+\mathrm{CC}
$$

Command area developments (CAD) of water infrastructure project are evaluated by the cropped area (CA), and drinking water supply. The cropped area is the product of regulatory constraints (RC) and water sharing issues (WSI). The observed conditions were grouped into class, ranked and assigned weightage (table 3$)$.

$\mathrm{CAD}=\sum(\mathrm{CA}$ rank $\mathrm{x}$ weightage $)+(\mathrm{RC}$ rank $\mathrm{x}$ weightage $)+($ WSI rank $\mathrm{x}$ weightage $)$

Table 3: $\quad$ Command area development assessment.

\begin{tabular}{|c|c|c|c|}
\hline Parameters & Class & Rank & Weightage \\
\hline \multirow{5}{*}{$\begin{array}{lll}\text { Cropped area } & \text { (reference } \\
\text { proposed) (CA) } & & \end{array}$} & $<10 \%$ & 5 & \multirow[t]{5}{*}{60} \\
\hline & $11-30 \%$ & 4 & \\
\hline & $31-50 \%$ & 3 & \\
\hline & $50-70 \%$ & 2 & \\
\hline & $71 \%>$ & 1 & \\
\hline \multirow{5}{*}{$\begin{array}{l}\text { Water flow Regulatory constraints } \\
\text { (RC) }\end{array}$} & $<10 \%$ & 5 & \multirow[t]{5}{*}{20} \\
\hline & $11-20 \%$ & 4 & \\
\hline & $21-30 \%$ & 3 & \\
\hline & $31-50 \%$ & 2 & \\
\hline & $51 \%>$ & 1 & \\
\hline \multirow[t]{5}{*}{ Water sharing issues (WSI) } & $<10 \%$ & 5 & \multirow[t]{5}{*}{10} \\
\hline & $11-30 \%$ & 4 & \\
\hline & $31-50 \%$ & 3 & \\
\hline & $50-70 \%$ & 2 & \\
\hline & $71 \%>$ & 1 & \\
\hline
\end{tabular}

The water infrastructure conditions of the existing systems evaluated on the above said methods is shown in table 4 .

\section{Results and discussion}

The goal of river basin development, planning and management is to promote sustainable development and integrate land and water management, by focusing natural resource benefits for regional planning and management strategy. There are six infrastructures having reservoir, canal and command area and others have only storages. Many of the reservoirs are storing below $50 \%$ of their capacity except R2, R3, R4, R5, R8, R9, R10, R12, R13, R14, R15 and R18. The canals are operating below it efficiency $(<50 \%)$, as the impediments for operation (blockage and water loss is high). There is an effective use of water availability in the command area ( $>50 \%)$, as indicated by the cropped area. 
Table 4: $\quad$ Sustainable performance of reservoir and canal and command area developments - Yerala river basin.

\begin{tabular}{|c|c|c|c|c|c|c|c|c|}
\hline \begin{tabular}{|c|} 
Reservoir \\
ID
\end{tabular} & Name & \begin{tabular}{|c|}
$\begin{array}{c}\text { Capacity } \\
\text { (MCM) }\end{array}$ \\
\end{tabular} & RSE & $\begin{array}{l}\text { Canal } \\
\text { length } \\
(\mathrm{km})\end{array}$ & CC & WIS & $\begin{array}{c}\text { Command } \\
\text { area } \\
(\mathrm{Sq} \mathrm{km})\end{array}$ & (CAD) \\
\hline R1 & $\begin{array}{l}\text { Yeralwadi } \\
\text { dam }\end{array}$ & 68.79 & 38.5 & $\begin{array}{l}\mathrm{L}-17.5 \\
\mathrm{R}-44.6\end{array}$ & $\begin{array}{l}42.2 \\
40.2\end{array}$ & 79.6 & $\begin{array}{l}\text { L- } 18.89 \\
\text { R- } 34.02\end{array}$ & $\begin{array}{l}60 \\
44\end{array}$ \\
\hline R2 & Ner Talav & 36.61 & 58.5 & $\begin{array}{l}\text { L }-4.00 \\
\text { R-36.19 }\end{array}$ & $\begin{array}{l}63 \\
44.2\end{array}$ & 112.75 & $\begin{array}{l}\mathrm{L}-1.4 \\
\mathrm{R}-26.36\end{array}$ & $\begin{array}{l}56 \\
60\end{array}$ \\
\hline R3 & Mayni Talav & 9.43 & 76.5 & 8.31 & 65 & 141.5 & 3.86 & 84 \\
\hline R4 & $\begin{array}{l}\text { Nimsode } \\
\text { Talav }\end{array}$ & 4.31 & 58.5 & & & & & \\
\hline R5 & $\begin{array}{l}\text { Shalgaon } \\
\text { Talav }\end{array}$ & 7.43 & 51.5 & & & & & \\
\hline R6 & $\begin{array}{l}\text { Karandewadi } \\
\text { Talav }\end{array}$ & 5.82 & 48.5 & & & & & \\
\hline R7 & Nerli Talav & 5.93 & 41.5 & & & & & \\
\hline R8 & Sonsal Talav & 9.70 & 51.5 & & & & & \\
\hline R9 & Alsund Talav & 5.38 & 66 & 5.3 & 44.2 & 110.2 & 7.92 & 58 \\
\hline R10 & $\begin{array}{l}\text { Lengare } \\
\text { Talav }\end{array}$ & 6.02 & 51.5 & & & & & \\
\hline R11 & Bamni Talav & 3.07 & 48.5 & & & & & \\
\hline R12 & $\begin{array}{l}\text { Bhendvade } \\
\text { Talav }\end{array}$ & 2.85 & 76 & & & & & \\
\hline R13 & $\begin{array}{l}\text { Morale Ped } \\
\text { Talav }\end{array}$ & 2.20 & 51.5 & & & & & \\
\hline R14 & $\begin{array}{l}\text { Hingangaon } \\
\text { Talav }\end{array}$ & 1.96 & 69 & & & & & \\
\hline R15 & $\begin{array}{l}\text { Chinchani } \\
\text { Talav }\end{array}$ & 3.76 & 51.5 & & & & & \\
\hline R16 & $\begin{array}{l}\text { Narsewadi } \\
\text { Talav }\end{array}$ & 3.04 & 41.5 & & & & & \\
\hline R17 & Trimali Talav & 1.52 & 48 & & & & & \\
\hline R18 & $\begin{array}{l}\text { Kankatre } \\
\text { Talav }\end{array}$ & 2.21 & 51 & 5.39 & 44.2 & 95.2 & 2.38 & 62 \\
\hline R19 & Darjai Talav & 4.60 & 41.5 & $\begin{array}{l}\text { L- } 10.74 \\
\text { R- } 17.65\end{array}$ & $\begin{array}{l}52.2 \\
48.2\end{array}$ & 91.7 & $\begin{array}{l}\text { L } 9.88 \\
\text { R- } 10.66\end{array}$ & $\begin{array}{l}68 \\
72\end{array}$ \\
\hline \multicolumn{2}{|c|}{ Total capacity } & 184.63 & & & & & & \\
\hline
\end{tabular}

The cumulative storage capacity of the infrastructures in the basin is about 184.63 TMC. Due to the sedimentation, they are able to store only $<50 \%$ of their capacity. Similarly, 170 tanks that are located in this basin have the storage capacity of $1.38 \mathrm{TMC}$, but sedimentation has reduced to its capacity to 0.69 TMC. As the rainfall pattern and intensity is changed over the past 5 to 6 years, there is a need to increase the capacity (by removal of sediments and repairing of embankments) of the storage system in meeting the requirements. 


\section{Conclusions}

Water storage and distribution systems in semi-arid regions need to be functionally effective in meeting the agriculture and drinking water demand, irrespective of rainfall pattern.

1. Water infrastructure condition (WIC) assessment of a river basin, based on Reservoir storage Efficiency (RSE), Canal Conditions (CC) and Command Area Development (CAD), assessed and evaluated from Yerala basin can be attempted in other semi-arid regions.

2. WIC could be an effective tool for decision making process, in river basin water resources development planning and management.

3. WIC would portray the water availability scenario under different climate change conditions.

\section{Acknowledgements}

The authors wish to record their support received from Indian Institute of Technology, Bombay, India. We benefitted from the discussion with Irrigation department of Government of Maharashtra, India and farmers in the basin area.

\section{References}

[1] Bos, M.G., Murray-Rust, D.H., Merrey, D.J., Johnson, H.G., \& Snellen, W.B., Methodologies for assessing performance of irrigation and drainage management. Irrigation and Drainage Systems, 7, pp. 231-262, 1994.

[2] Y.S. Kukul, S. Akçay, S. Anaç \& E. Yeşilırmak, Temporal irrigation performance assessment in Turkey: Menemen case study. Agricultural water management 95, pp. 1090 - 1098, 2008.

[3] Kjeldsen, T.R., and Rosbjerg, D., Choice of reliability, resilience and vulnerability estimators for risk assessments of water resources systems. Hydrological Science Journal, 49 (5), pp. 755-767, 2004.

[4] Sharad K. Jain, Investigating the behavior of statistical indices for performance assessment of a reservoir. Journal of Hydrology, 391, pp. 9096, 2010.

[5] Vogel, R.M., and Bolognese, R.A., Storage-reliability-resilience - yield relations for over - year water supply systems. Water Resources Research, 31 (3), pp. 645-654, 1995.

[6] Molden, D., and Gates, T.K., Performance measures for evaluation of Irrigation water delivery systems. Journal of Irrigation and Water Engineering, ASCE 116 (6), 804-823, 1990.

[7] Kloezen, W.H., and Garce's-Restrepo, C., Assessing irrigation performance with comparative indicators: the case of the Alto Rio Lerma Irrigation District, Mexico. International Water Management Institute (IWMI) Research Report No. 22. Colombo, Sri Lanka, 1998.

[8] Abhijit M. Zende, R. Nagarajan, and K. R. Atal, Performance assessment of Lift Irrigation Projects - Takari Lift Irrigation Scheme (TLIS) - Yerala 
River Krishna River, India. International journal of Energy and Environmental Engineering, 2012, [in press].

[9] Srinivasa Raju, K., Studies on Multi-criterion Decision Making methods and Management of Irrigation systems. Ph.D Thesis, Indian Institute of Technology, Kharagpur, India, 1995. 